\title{
Growth, biomass production and nutrient accumulation of Macaranga gigantea in response to NPK fertilizer application
}

\author{
DWI SUSANTO $^{1, \boldsymbol{\varphi}}$, SRI MULYATI ${ }^{1}$, HERI PURNOMO ${ }^{1}$, DADDY RUHIYAT ${ }^{2}$, RUDIANTO AMIRTA ${ }^{2}$ \\ ${ }^{1}$ Department of Biology, Faculty of Mathematics and Natural Sciences, Universitas Mulawarman. Jl. Barong Tongkok No. 4, Gunung Kelua, Samarinda- \\ 75123, East Kalimantan, Indonesia. Tel./Fax.: +62-541-749140, 749152, 749153, "email: susantodwiki@ yahoo.com \\ ${ }^{2}$ Faculty of Forestry, Universitas Mulawarman. Jl. Ki Hajar Dewantara Kampus Gunung Kelua, Samarinda-75123, East Kalimantan, Indonesia
}

Manuscript received: 23 November 2016. Revision accepted: 31 August 2017.

\begin{abstract}
Susanto D, Mulyati S, Purnomo H, Ruhiyat D, Amirta R. 2017. Growth, biomass production and nutrient accumulation of Macaranga gigantea in response to NPK fertilizer application. Nusantara Bioscience 9: 330-337. Research described in this paper investigated the effect of fertilizer application on the growth, biomass production and nutrient accumulation of mahang (Macaranga gigantea) plant components. The experiment was carried out in a research area of the Faculty of Forestry, Mulawarman University, Samarinda, East Kalimantan. The effects of five dose levels of an NPK (16-16-16) fertilizer on the growth rate of mahang seedlings planted in field conditions were compared. The treatments consisted of a control group (with no fertilizer), and dosages of $40 \mathrm{~g}$, $80 \mathrm{~g}$, $120 \mathrm{~g}$ and $160 \mathrm{~g}$ per plant. Fertilization at those levels was applied twice: the first application at four weeks after the planting and the second application at 6 months after the first. Growth rates between treatments were compared over a twelve month period. The research findings revealed that as the dosages of fertilizer increased, so the growth, biomass production and nutrient accumulation in components of the plants also increased. The best growth was found in the treatment in which fertilizer was applied (twice) at a dosage of $120 \mathrm{~g}$ per plant; at this dose level, by twelve months of age, the stem basal diameter had reached $45.2 \pm 4.9 \mathrm{~cm}$, stem height $219.2 \pm 39.1 \mathrm{~cm}$, number of leaves per plant $17.3 \pm 1.2$, and canopy diameter $246.7 \pm 25.0 \mathrm{~cm}$. The highest production of above-ground biomass was also found in the fertilizer treatment of $120 \mathrm{~g}$ per plant; the largest proportion of the biomass was in the leaves, followed by the wood, and then bark. The nutrient element that had accumulated most in plants at 1 year of age was potassium, followed by phosphorus and then nitrogen. The highest nitrogen uptake of stands was found in the NPK fertilization with a dosage of $160 \mathrm{~g}$ per tree, while the highest phosphorus and potassium uptake was found at a fertilizer dosage of $120 \mathrm{~g}$ per tree. The amount of nutrients accumulated in producing one tonne of above-ground biomass increased in response to different fertilization treatments. The fertilizer treatment of $120 \mathrm{~g}$ per plant (applied twice; the first soon after planting and the next after 6 months) resulted in the accumulation within the 1 year old plants of $2.38 \mathrm{~kg}$ of nitrogen, $6.36 \mathrm{~kg}$ of phosporus and $17.83 \mathrm{~kg}$ of potassium, with an $\mathrm{N}: \mathrm{P}: \mathrm{K}$ ratio of $13.3: 35.6: 100$. The availability of the element potassium needs special attention when this species is cultivated.
\end{abstract}

Keywords: Macaranga gigantea, pioneer species, growth, biomass production and nutrient accumulation

\section{INTRODUCTION}

The global fuel crisis has stimulated the development of alternative renewable biofuel energy sources. Utilization of biofuels, derived from agricultural crops like sugarcane, corn, cassava, palm wine, and oil palm, converted into ethanol, presents challenges as well as opportunities. Various efforts made to optimize these biofuel industries have implications for agricultural production and on prices of food materials. Liquid bioethanol derived from wood is an alternative to the use of agricultural crops in biofuel production and could be sustainable as long as the forests are managed sustainably.

One type of soft wood that could be used for this purpose is produced by the forest tree species Macaranga gigantea (Rchb.f. \& Zoll.) Müll.Arg. The production of wood from this tree varies from $320 \mathrm{~kg}^{3} \mathrm{~m}^{-1}$ (low), to 370 $\mathrm{kg}^{3} \mathrm{~m}^{-1}$ (medium), to $460 \mathrm{~kg}^{3} \mathrm{~m}^{-1}$ (high), with a water content of 35\% (Suzuki 1999). Based on chemical analysis of $M$ gigantea biomass, it is found to contain $24.4 \%$ lignin. $71.14 \%$ holocellulose, and $46.67 \% \alpha$-cellulose (Amirta et al. 2016b). Enzymatic hydrolysis of this plant produces the highest reduced sugar (82.47\%) if compared with other types of wood which are potential to develop as raw material for ethanol (Amirta et al. 2010).

Information about the cultivation of this plant is rare. M. gigantea grows naturally in lowland tropical rainforests, especially in gaps that result from timber harvesting, forest fires, and shifting cultivation (Lawrence 2005; Eichorn 2006; Silk 2008). This plant is a pioneer species which requires high levels of light in extensive forest gaps and secondary forest habitats (Davies et al. 1998; Romell et al. 2008). The percentage and rate of germination of seeds extracted through the wet extraction process are higher than those extracted through the dry extraction process. Highest rates of germination $(65 \%)$ have been reported from seeds extracted through the wet extraction process and grown on compost media (Susanto et al. 2016a). Nussbaum at al. (1995) states that nutrient deficiency is an important factor that hinders the initial growth of Dipterocarpaceae plants (Dryobalonops lanceolata and Shorea leprosula) planted simultaneously with pioneer species (M. gigantea and $M$. hipoleuca) at the age of 6 months in the degraded lands of unused log stock piling areas and roadworks in Malaysia. 
Susanto et al. (2016a) investigated the relative growth rate of seedlings planted on different planting media and found that mushroom spawn waste media resulted in the highest rate $(0.36 \pm 0.42 \%)$, followed by compost media $(0.15 \pm 0.09 \%)$, top soil media $(0.10 \pm 0.04 \%)$ and sand media $(0.10 \pm 0.07 \%)$. According to Okuda (1996), seedlings of $M$. gigantea produce their leaves and shed them every 18.86 and 16.75 days respectively, while their leaves reach their full extent in 20.8 days and their twigs their full length in 91.8 days. Photosynthetic capacity increases rapidly during the development of leaves, reaching a maximum as soon as the leaves reach their full extent and then decreasing with increasing age. Effective placement of young leaves on the plant creates a high capacity for photosynthesis to increase the capture of carbon by the whole plant. The seedlings of $M$. gigantea reduce self-shading of their leaves by increase in the petiole length and in the angle between petiole and the upright main stem, from youngest to oldest leaves on the plant (Okuda et al. 1996; Yamada et al. 2000).

Seedlings of $M$. gigantea grow rapidly over the first 18 weeks when planted in polybags if supplied with a combination of nitrogen and phosphorus fertilizers (Lawrence 2001). Ishida et al. (2005) reported that the lowest total photosynthesis rate per unit leaf area in M.gigantea is found at the seedling stage and the highest at the sapling stage. The leaves at the sapling stage have the highest nitrogen concentration, total photosynthesis rate, and stomatal conductance, indicating that the gradual transition from seedling stage to sapling stage is accompanied by accumulating $\mathrm{N}$ in the plant body and development of effiency of the plant's water transport system to face unpredictable environmental stresses.

Our research reported in this paper focused on an experiment examining the effect of dose level of an NPK fertilizer on the growth of $M$. gigantea planted in a monoculture system in an open field. The growth in total above-ground biomass and of its component plants parts was measured, and the accumulation of nutrient elements $\mathrm{N}, \mathrm{P}$ and $\mathrm{K}$ in the plant components at the age of one year was determined, as a practical step in optimising the potential industrial cultivation of this useful forest species.

\section{MATERIALS AND METHODS}

\section{Study area}

This research was conducted in the research forest of the Faculty of Forestry, Mulawarman University, Samarinda, East Kalimantan $\left(0^{0} .44^{\prime} 71.11^{\prime}\right.$ 'South and 117.21'67.50" East) (Figure 1). Data from 2003 to 2012 shows that the average annual rainfall over that period was $2423 \mathrm{~mm}$, and that the highest annual rainfall was 2757.5 $\mathrm{mm}$ in 2008. The highest monthly rainfall was in April $(288.3 \mathrm{~mm})$ and the lowest in August $(115.3 \mathrm{~mm})$. The wet season varied from 9 to 12 months, and the dry season from 0 to 3 months. Average monthly temperature was $27.5^{\circ} \mathrm{C}$ and average air humidity was $82 \%$ (Anonymous 2012). Chemical properties of the soil in the research plots over the depth of $0-30 \mathrm{~cm}$ are as follows: $\mathrm{pH}$ : 4.97 , cation exchange capacity: 7.06 meq. $100 \mathrm{~g}^{-1}$, base saturation: $7.45 \%$, and bulk density: $1.16 \mathrm{~g}$. $\mathrm{ml}^{-1}$, and soil nutrients concentration are C Organic: $1.45 \%, \mathrm{~N}: 0.12 \%, \mathrm{P}: 3.61 \mathrm{ppm}$, $\mathrm{K}: 67.48$ ppm, Ca: 1.17 cmol. $\mathrm{kg}^{-1}, \mathrm{Mg}: 0.13 \mathrm{cmol} . \mathrm{kg}^{-1}$.

\section{Procedures \\ Preparing seedlings}

Seedling were obtained by germinating $M$. gigantea seed collected from ripe fruits of parent trees in the Botanical Garden of Mulawarman University, Samarinda. The seeds obtained from the parent trees were spread on soil beds. When the seeds were germinated and 2-3 leaves had appeared, the seedlings were then planted in polybags filled with growing media in the form of a mixture of topsoil, rice husks, and chicken manure (4:1:1). Seedlings aged 3 months, with average height $257 \pm 3.8 \mathrm{~mm}$, basal stem diameter $5.2 \pm 1.3 \mathrm{~mm}$ and with number of leaves $4.7 \pm 2.4$, were ready to plant in the research plots.

\section{Land preparation}

Initial vegetation found in the research location was in the form of bushes dominated by Melastoma $s p$ and saplings of pioneer plants such as Macaranga. The land was prepared by clearcutting the area and this was carried out manually by exploring, cutting, slashing and burning. Planting holes were prepared at a spacing of $3 \mathrm{~m} \times 3 \mathrm{~m}$. The size of each planting hole was $30 \mathrm{~cm}$ x $30 \mathrm{~cm}$ x $30 \mathrm{~cm}$. The total size of the research plot was $50 \times 90 \mathrm{~m}$.

\section{Experimental design}

The trial was set up with five randomized treatments plots with 3 block (each containing 20 plants, making 20 x 5 x $3=300$ plants in the entire trial area). The treatments were five dosages of NPK fertilizer (16-16-16), consisting of a control (with no fertilizer), and either $40 \mathrm{~g}, 80 \mathrm{~g}, 120 \mathrm{~g}$ or $160 \mathrm{~g}$ applied per plant. Fertilization was carried out twice. The first application was four weeks after the planting and the second application was applied 6 months after the first application. Measurement of growth performance was carried out every three months from the time of planting up to final sampling at 12 months.

\section{Planting}

Seedlings in polybags were placed at the sides of the prepared planting holes. The polybags were opened carefully with a knife, then the seedlings were placed into the planting holes which were then backfilled with soil. Every plant was identified by a wooden stake 1 meter long, and numbered. Every treatment sub-plot and research block was marked. One month after planting, the plants were fertilized using a compound NPK fertilizer (16\% N: $16 \%$ $\mathrm{P}_{2} \mathrm{O}_{5}: 16 \% \mathrm{~K}_{2} \mathrm{O}, 1.5 \% \mathrm{MgO}$, and $5 \% \mathrm{CaO}$ ), with an amount given to each plant in accordance with the requirements of the experimental design. The fertilizer was applied by broadcasting it around the sampling stem within a circular pattern of radius $50 \mathrm{~cm}$. A second round of fertilization was applied six months after the first fertilization. Weeds were removed from the research plots manually, whenever this was needed. 

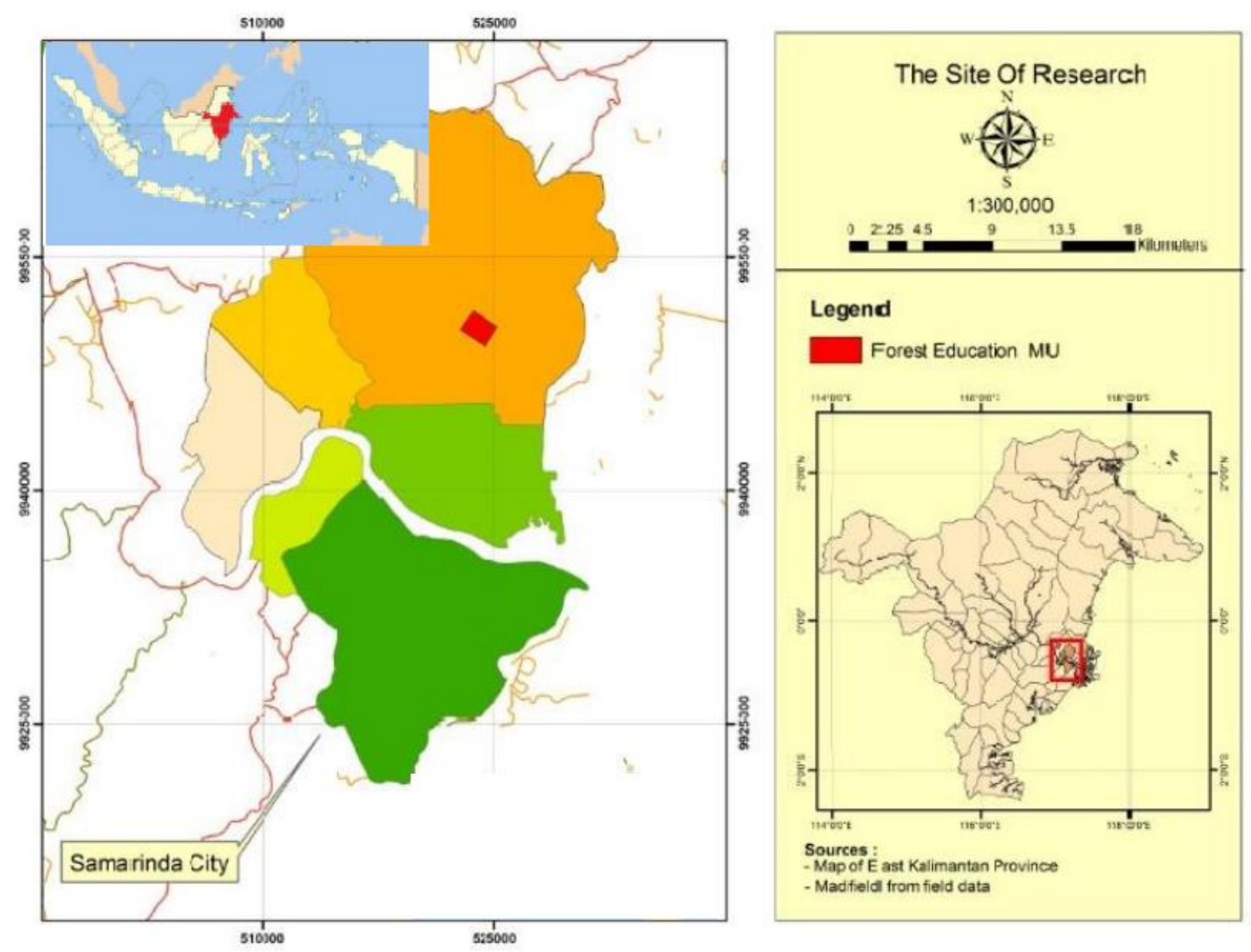

Figure 1. Map of study area in the Research Forest, Faculty of Forestry, Mulawarman University, Samarinda, East Kalimantan, Indonesia

\section{Soil analysis}

The soil in the trial area was sampled at the beginning of the planting period (before the application of fertilizer). The bulk density of a sample (0-30 cm depth) whose volume had been determined, was calculated after the sample was dried in an oven at a temperature of $150^{\circ} \mathrm{C}$ until constant weight was reached. A composite sample was wind-dried and its $\mathrm{pH}$, base saturation, cation exchange capacity, organic carbon content, total Nitrogen (Kjeldahl), available phosphorus (Bray), and available potassium were measured.

\section{Plant measurement}

The $M$. gigantea plants were measured in terms of their stem heights, basal stem diameters, number of leaves, canopy diameters, all of which were measured at the beginning of the planting and every three months until the plants reached the age of 12 months.
The sampling of $\mathrm{M}$. gigantea biomass

The measurement of biomass in the experiment was limited only to plant components above the ground. The biomass of trees that were the sampled within one stand was used to calculate the biomass of all the trees within a particular plot. The trees sampled from one plot were selected after all the available trees were grouped into three stages based on their estimated size according to the formula $\mathrm{D}^{2} \mathrm{H}$ (diameter squared multiplied by height). The entire stand biomass was calculated by multiplying the dry weight of the components of the sampled tree by the number of trees in each stage, and then it was converted into a biomass per hectare. One year after planting, 3 plants were randomly sampled from each of the five fertilizer treatments, and then they were felled. The wet weight of every component was measured, including wood, barks and leaves (Ruhiyat 1996). Samples of the wood, barks and leaves were weighed wet and dry. The plant samples were taken to the laboratory and their nutrient contents $(\mathrm{N}, \mathrm{P}$ and $\mathrm{K})$ were analyzed. 
Analysis of nutrient concentration of plant components

The total $\mathrm{N}$ concentrate was measured using the Kjeldahl method (extraction, distillation, and titration). To measure the elements $\mathrm{P}$ and $\mathrm{K}$, the plant components were extracted using the High Pressure Digestion method at a temperature of $180^{\circ} \mathrm{C}$ for 10 hours with $\mathrm{HNO}_{3}$ as the reductant. Phosphorus was measured using a calorimetric technique with nitrate-molybdate-vanadate acid as the coloring agent and a spectrophotometer at the wavelength of $470 \mathrm{~nm}$. Potassium was measured using an Atomic Absorption Spectrophotometer at wavelengths of $766.5 \mathrm{~nm}$, $489.5 \mathrm{~nm}$ and $245.2 \mathrm{~nm}$. To calculate the total macro nutrient elements $(\mathrm{N}, \mathrm{P}, \mathrm{K})$ accumulated in the tree components in the stand, the dry weights of the tree components were multiplied by their nutrient concentrations.

\section{Data analysis}

The growth rate data were analyzed using analysis of variance (ANOVA) and further tested using Duncan's
Multiple Range Test (DMRT) at significance level of $95 \%$. Data for soil and plant nutrient concentrations were analyzed descriptively.

\section{RESULTS AND DISCUSSION}

\section{Plant growth}

Fertilizer application had a significant effect on the growth of mahang seedlings. Best growth was when the NPK fertilizer was applied (twice) at a dosage of $120 \mathrm{~g}$ per plant, followed by $160 \mathrm{~g}, 80 \mathrm{~g}, 40 \mathrm{~g}$ and $0 \mathrm{~g}$. Treatment T3 (120 g fertilizer per plant applied at planting and then repeated at 6 months) produced a basal stem diameter of $45.2 \pm 4.9 \mathrm{~mm}$, stem height of $219.2 \pm 39.1$, number of leaves of $17.3 \pm 1.2$ and canopy diameter of $246.7 \pm 25.0 \mathrm{~cm}$, twelve months after planting seedlings in the field (Table 1; Figure 2-3).

Table 1. The effect of fertilizer treatment on growth of Macaranga gigantea: basal stem diameter, stem height, leaf number per plant and crown diameter, at 6 months and 12 months after planting seedlings in the field. Values followed by the same letter within the same column do not differ significantly $(p<0.05)$.

\begin{tabular}{lcccccccc}
\hline Fertilizer & \multicolumn{2}{c}{ Basal diameter (mm) } & \multicolumn{2}{c}{ Height $(\mathbf{c m})$} & \multicolumn{2}{c}{ ELeaves } & \multicolumn{2}{c}{ Crown diameter (cm) } \\
\cline { 2 - 9 } & 6 month $^{12}$ month & 6 month & 12 month & 6 month & 12 month & 6 month & 12 month \\
\hline $0 \mathrm{~g}$ & $15.5 \pm 1.6^{\mathrm{a}}$ & $34.1 \pm 5.3^{\mathrm{a}}$ & $65.1 \pm 8.3^{\mathrm{a}}$ & $175.6 \pm 34.1^{\mathrm{a}}$ & $6.9 \pm 0.5^{\mathrm{a}}$ & $13.8 \pm 2.1^{\mathrm{a}}$ & $118.4 \pm 20.7^{\mathrm{a}}$ & $210.5 \pm 33.0^{\mathrm{a}}$ \\
$40 \mathrm{~g}$ & $16.9 \pm 4.1^{\mathrm{a}}$ & $35.4 \pm 5.7^{\mathrm{a}}$ & $66.75 \pm 7.9^{\mathrm{a}}$ & $172.7 \pm 28.2^{\mathrm{a}}$ & $6.9 \pm 0.4^{\mathrm{a}}$ & $14.2 \pm 2.2^{\mathrm{a}}$ & $125.4 \pm 13.8^{\mathrm{a}}$ & $219.8 \pm 23.2^{\mathrm{ab}}$ \\
$80 \mathrm{~g}$ & $18.7 \pm 1.7^{\mathrm{a}}$ & $40.6 \pm 2.1^{\mathrm{b}}$ & $69.8 \pm 4.8^{\mathrm{bc}}$ & $195.8 \pm 13.5^{\mathrm{ab}}$ & $7.9 \pm 0.3^{\mathrm{b}}$ & $17.7 \pm 2.9^{\mathrm{b}}$ & $128.1 \pm 7.0^{\mathrm{a}}$ & $227.2 \pm 19.6^{\mathrm{ab}}$ \\
$120 \mathrm{~g}$ & $23.1 \pm 6.1^{\mathrm{b}}$ & $45.2 \pm 4.9^{\mathrm{bc}}$ & $84.7 \pm 16.7^{\mathrm{c}}$ & $219.2 \pm 39.1^{\mathrm{b}}$ & $7.9 \pm 0.4^{\mathrm{b}}$ & $17.3 \pm 1.2^{\mathrm{b}}$ & $148.2 \pm 29.0^{\mathrm{b}}$ & $246.7 \pm 25.0^{\mathrm{c}}$ \\
$160 \mathrm{~g}$ & $18.8 \pm 3.6^{\mathrm{a}}$ & $42.9 \pm 3.7^{\mathrm{c}}$ & $77.85 \pm 13.1^{\mathrm{b}}$ & $211.4 \pm 19.4^{\mathrm{b}}$ & $8.2 \pm 0.5^{\mathrm{b}}$ & $16.1 \pm 1.3^{\text {ab }}$ & $130.2 \pm 14.2^{\mathrm{a}}$ & $236.3 \pm 6.8^{\mathrm{b}}$ \\
\hline
\end{tabular}
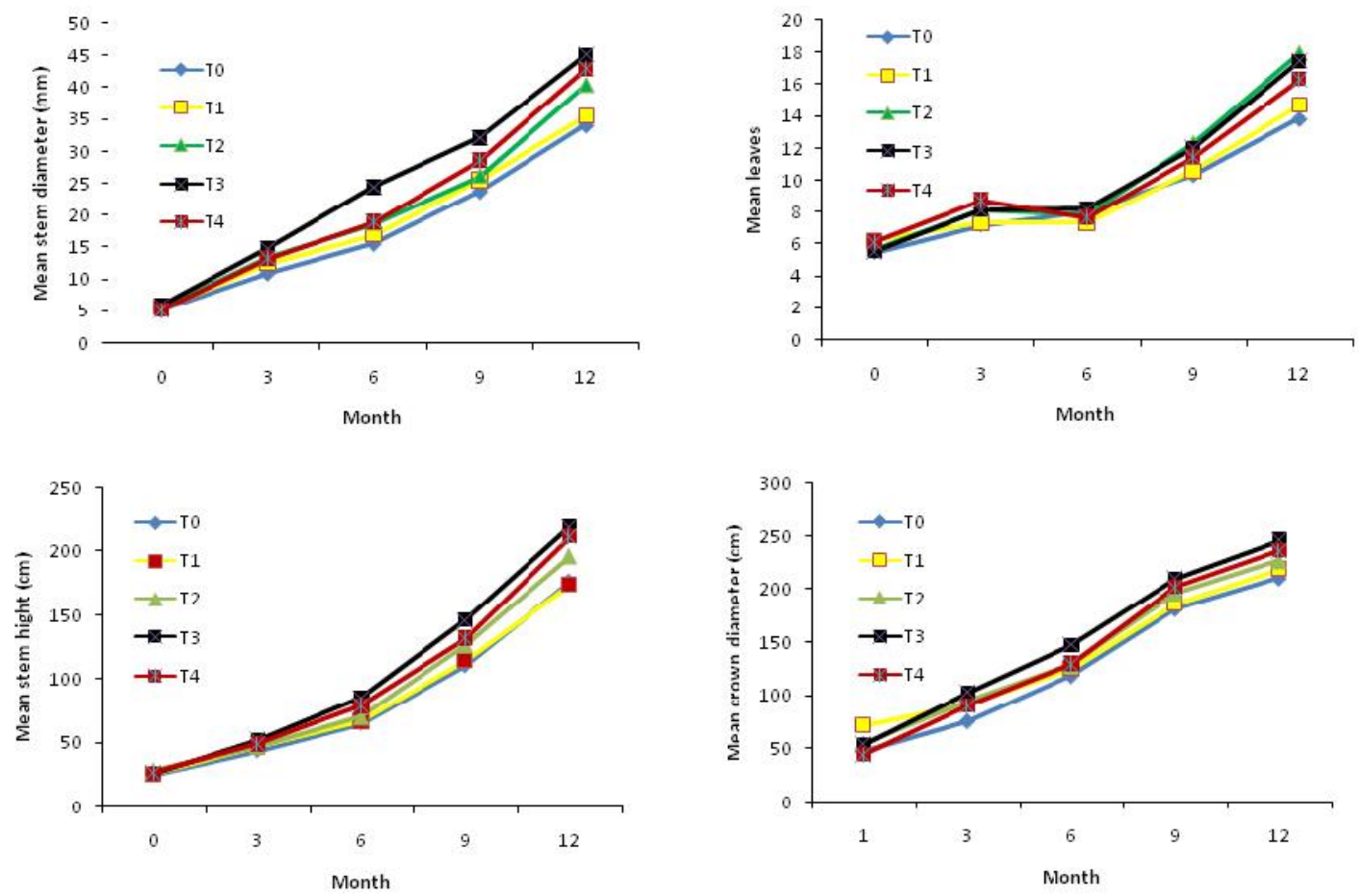

Figure 2. Growth statistics for M. gigantea, 3, 6, 9 and 12 months after planting: basal stem diameter; stem height, number of leaves per plant and crown diameter 

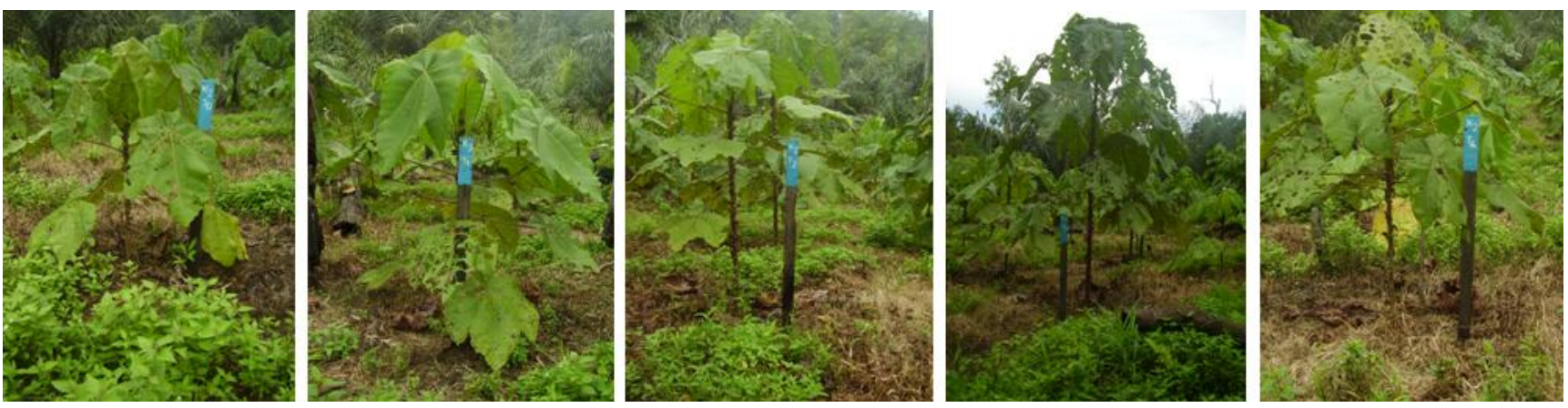

Figure 3. $M$. gigantea plants in the field, 12 months after planting out the seedlings. The photographs, from left to right, are of plants growing in treatment plots $\mathrm{T} 0, \mathrm{~T} 1, \mathrm{~T} 2, \mathrm{~T} 3$ and $\mathrm{T} 4,(0,40 \mathrm{~g}, 80 \mathrm{~g}, 120 \mathrm{~g}$ and $160 \mathrm{~g}$ fertilizer per plant).

\section{Plant biomass}

The estimated above-ground biomass increased due to the fertilization treatments. The highest production was found in the treatment with $120 \mathrm{~g}$ fertilizer, which reached a total above-ground biomass of $2255.3 \mathrm{~kg} \mathrm{ha}^{-1}$, consisting of $32.3 \%$ wood, $9.6 \%$ bark and $58.1 \%$ leaves. This was followed by fertilizer treatments $160 \mathrm{~g}, 80 \mathrm{~g}, 40 \mathrm{~g}$, and $0 \mathrm{~g}$ (Table 2). Leaves were the largest component of the biomass, followed by stemwood and then stembark.

\section{Nutrient concentration in the soil and plants}

Fertilizer treatment increased the concentration of N, P, $\mathrm{K}$ in the leaves measured twelve months after planting. The highest leaf concentrations of each nutrient were all found at the highest fertilizer dosage, of $160 \mathrm{~g}$ per plant (applied twice): i.e. $0.81 \%$ for leaf Nitrogen, $0.73 \%$ for leaf Phosphorous, and $1.35 \%$ for leaf Potassium.(Table 3). The highest soil nutrient found in $160 \mathrm{~g}$ (nitrogen and phosphorus) and $120 \mathrm{~g}$ (potassium) (Table 3 ).

\section{Nutrient content of plant components}

Fertilizer treatments increased the accumulation of nutrient elements $\mathrm{N}, \mathrm{P}$, and $\mathrm{K}$ in the above-ground plant biomass. The highest accumulation of nitrogen was found in the highest fertilization treatment $160 \mathrm{~g}$ per plant, reaching $7.3 \mathrm{~kg} \mathrm{ha}^{-1}$ in the leaves. Treatment T3 (120 g fertilizer per plant) showed the highest accumulation of phosphorus, reaching $7.2 \mathrm{~kg} \mathrm{ha}^{-1}$, also in leaves. The highest accumulation of potassium was found in $\mathrm{T} 2$, the 80 $\mathrm{g}$ fertilizer per plant treatment reaching $15.9 \mathrm{~kg} \mathrm{ha}^{-1}$ in stemwood. (Table 4; Figure 4)

The estimated nutrient elements accumulated by 1 -yearold $M$. gigantea plants in producing one tonne biomass and the ratio of $\mathrm{N}: \mathrm{P}: \mathrm{K}$ for annual biomass production is presented in Table 5. One of the most important parameters in analyzing the nutrient accumulation and concentration in plant biomass is the ratio of the nutrient elements of $\mathrm{N}: \mathrm{P}: \mathrm{K}$ accumulated in the production of one tonne of biomass. Fertilization treatments created variation in the ratio of accumulated N:P:K. Treatment T3 (120 g fertilizer per plant applied twice) produced the largest estimated biomass, with an N:P:K ratio of 13.3:35.6:100 (Table 5).

\section{Discussion}

There is little published information about the quantity of nutrient elements required for growth and biomass production of $M$. gigantea plants, especially those growing in plantations. In Malaysia, pioneer plants of $M$. gigantea and $M$. hypoleuca species planted together with Dryobalonops lanceolata and Shorea leprosula (Dipterocarpaceae) on degraded soil were shown to respond to fertilization (Nusbaum et al. 1995). Seedlings had increased in dry weight, basal diameter, and height for each species at the age of 6 months. The increase in relative height and basal diameter of fertilized $M$. gigantea seedlings was four times higher than for unfertilized plants otherwise treated the the same. Their canopy diameter reached $100 \mathrm{~cm}$ in six months (Nusbaum et al. 1995). In our study, the canopy diameter of fertilized $M$. gigantea at the age of 12 months reached $246.7 \pm 25.0 \mathrm{~cm}$, which was quite comparable with the values obtained in the Malaysian study.

Research on secondary forest gaps in Malaysia has shown an average increment in diameter at breast height of M. gigantea of $4.0 \mathrm{~mm} \mathrm{y}^{-1}$ to $4.5 \mathrm{~mm} \mathrm{y}^{-1}$ with a maximum rate of $6.6 \mathrm{~mm} \mathrm{y}^{-1}$ to $7.8 \mathrm{~mm} \mathrm{y}^{-1}$ (Manokaran and Kochument 1992). Davies et al. (1998) reported that the growth in diameter of $M$. gigantea was $0.22 \mathrm{~mm} \mathrm{y}^{-1}$ in the seedling stage; $0.37 \mathrm{~mm} \mathrm{y}^{-1} \mathrm{r}$ in the sapling stage; $0.74 \mathrm{~mm}$ $\mathrm{y}^{-1}$ in the reproductive stage; and $0.39 \mathrm{~mm} . \mathrm{y}^{-1}$ in the mature stage. Hiratsuka et al. (2006) stated that the average stem diameter of $M$. gigantea at the age of three years after forest fire in East Kalimantan, Indonesia was 4.64.6 \pm 2.6 $\mathrm{cm}$. Compared with these estimates of growth of $M$. gigantea in nature, in our study the increments in diameter and height of fertilized mahang plants were far higher.

Research on secondary forest gaps in Malaysia has shown that the median diameter growth rate of $M$. gigantea of $4.0 \mathrm{~mm} \mathrm{y}^{-1}$ to $4.5 \mathrm{~mm} \mathrm{y}^{-1}$ with a maximum rate of 6.6 $\mathrm{mm} \mathrm{y}^{-1}$ to $7.8 \mathrm{~mm} \mathrm{y}^{-1}$ (Manokaran and Kochument 1992). Davies et al. (1998) reported that the median diameter growth rate of $M$. gigantea was $0.22 \mathrm{~mm} \mathrm{y}^{-1}$ in the seedling stage; $0.37 \mathrm{~mm} \mathrm{y}^{-1} \mathrm{r}$ in the sapling stage; $0.74 \mathrm{~mm} \mathrm{y}^{-1}$ in the reproductive stage; and $0.39 \mathrm{~mm} . \mathrm{y}^{-1}$ in the mature stage. Hiratsuka et al. (2006) stated that the average stem 
diameter of $M$. gigantea at the age of three years after forest fire in East Kalimantan, Indonesia was $4.6 \pm 2.6 \mathrm{~cm}$. Compared with these estimates of growth of mahang in nature, in our study the increments in diameter and height of fertilized $M$. gigantea plants were far higher.

In a study by Nusbaum et al. (1995), the average dry weight at age 6 months of $M$. gigantea grown on a degraded soil without fertilization was $4.18 \mathrm{~g}$, while the average dry weight of fertilized plants reached $250 \mathrm{~g}$ (above-ground biomass was $198 \mathrm{~g}$ ). In our study, the most effective fertilizer treatment (120 g of NPK fertilizer per plant) produced an above-ground biomass yield of 2255.3 $\mathrm{kg} \mathrm{ha}^{-1}$.

Table 2. Estimated above-ground biomass in three components (wood, bark and leaves) of trees in the five different fertilizer treatments twelve months after planting out the seedlings

\begin{tabular}{|c|c|c|c|c|c|c|}
\hline \multirow[b]{2}{*}{$\begin{array}{l}\text { Fertilizer } \\
\text { treatment }\end{array}$} & \multicolumn{2}{|c|}{ Stemwood } & \multicolumn{2}{|c|}{ Stembark } & \multicolumn{2}{|c|}{ Leaves } \\
\hline & $\begin{array}{c}\text { kg } \\
\text { plot }^{-1}\end{array}$ & $\mathrm{~kg} \mathrm{ha}^{-1}$ & $\begin{array}{c}\text { kg } \\
\text { plot }^{-1}\end{array}$ & $\mathrm{~kg} \mathrm{ha}^{-1}$ & $\begin{array}{c}\text { kg } \\
\text { plot }^{-1}\end{array}$ & $\mathrm{~kg} \mathrm{ha}^{-1}$ \\
\hline $0 \mathrm{~g}$ & 12.3 & 310.7 & 4.6 & 114.7 & 31.9 & 807.6 \\
\hline $40 \mathrm{~g}$ & 12.7 & 319.9 & 5.3 & 131.5 & 26.2 & 663.3 \\
\hline $80 \mathrm{~g}$ & 25.1 & 634.1 & 8.7 & 218.2 & 34.3 & 866.1 \\
\hline $120 \mathrm{~g}$ & 28.9 & 728.46 & 8.5 & 216.5 & 51.9 & 1310.3 \\
\hline $160 \mathrm{~g}$ & 24.9 & 629.4 & 9.6 & 243.3 & 45.1 & 1138.3 \\
\hline
\end{tabular}

Table 3. Soil nutrient at $0-30 \mathrm{~cm}$ deep and leaf nutrient concentration after fertilizer treatment (1 year)

\begin{tabular}{lcccccc}
\hline \multirow{2}{*}{$\begin{array}{c}\text { Fertilizer } \\
\text { treatment }\end{array}$} & \multicolumn{2}{c}{ Nitrogen } & \multicolumn{2}{c}{ Phosphorus } & \multicolumn{2}{c}{ Potassium } \\
\cline { 2 - 7 } & $\begin{array}{c}\text { Soil } \\
(\%)\end{array}$ & $\begin{array}{c}\text { Leaves } \\
(\boldsymbol{\%})\end{array}$ & $\begin{array}{c}\text { Soil } \\
(\mathbf{p p m})\end{array}$ & $\begin{array}{c}\text { Leaves } \\
(\boldsymbol{\%})\end{array}$ & $\begin{array}{c}\text { Soil } \\
(\mathbf{p p m})\end{array}$ & $\begin{array}{c}\text { Leaves } \\
(\boldsymbol{\%})\end{array}$ \\
\hline $0 \mathrm{~g}$ & 0.11 & 0.28 & 20.82 & 0.69 & 101.14 & 1.13 \\
$40 \mathrm{~g}$ & 0.10 & 0.34 & 22.10 & 0.73 & 124.74 & 1.10 \\
$80 \mathrm{~g}$ & 0.10 & 0.30 & 19.70 & 0.65 & 75.81 & 0.99 \\
$120 \mathrm{~g}$ & 0.10 & 0.28 & 23.90 & 0.71 & 179.96 & 1.01 \\
$160 \mathrm{~g}$ & 0.13 & 0.81 & 32.64 & 0.73 & 99.56 & 1.35 \\
\hline
\end{tabular}

Table 4. Effect of fertilizer treatment on the amount $\left(\mathrm{kg} \mathrm{ha}^{-1}\right)$ of $\mathrm{N}, \mathrm{P}, \mathrm{K}$ accumulated in the stemwood, stembark, leaves of 1 year old Macaranga gigantea.

\begin{tabular}{|c|c|c|c|c|c|c|}
\hline \multirow{2}{*}{$\begin{array}{l}\text { Fertilizer } \\
\text { treatment }\end{array}$} & \multirow{2}{*}{ Tree section } & \multicolumn{5}{|c|}{ Nutrient content $\left(\mathrm{kg} \mathrm{ha}^{-1}\right)$} \\
\hline & & $\mathbf{N}$ & $\mathbf{P}$ & $\mathbf{K}$ & $\mathrm{Ca}$ & Mg \\
\hline \multirow[t]{4}{*}{$0 \mathrm{~g}$} & Stemwood & 0.39 & 1.38 & 2.85 & 1.09 & 0.37 \\
\hline & Stembark & 0.22 & 0.56 & 2.01 & 0.73 & 0.36 \\
\hline & Petiole & 0.22 & 0.99 & 3.76 & 0.82 & 0.40 \\
\hline & Leaves & 1.79 & 4.42 & 7.40 & 1.05 & 0.53 \\
\hline \multirow[t]{4}{*}{$40 \mathrm{~g}$} & Stemwood & 0.54 & 1.97 & 6.09 & 0.72 & 0.44 \\
\hline & Stembark & 0.25 & 0.69 & 1.93 & 2.16 & 0.58 \\
\hline & Petiole & 0.89 & 1.05 & 5,80 & 2.29 & 0.51 \\
\hline & Leaves & 1.35 & 3.57 & 5.18 & 1.82 & 0.56 \\
\hline \multirow[t]{4}{*}{$80 \mathrm{~g}$} & Stemwood & 1.41 & 3.85 & 15.89 & 2.05 & 0.67 \\
\hline & Stembark & 0.24 & 1.26 & 4.09 & 1.57 & 0.64 \\
\hline & Petiole & 0.25 & 1.24 & 7.66 & 1.60 & 0.63 \\
\hline & Leaves & 1.90 & 4.02 & 5.86 & 1.21 & 0.48 \\
\hline \multirow[t]{4}{*}{$120 \mathrm{~g}$} & Stemwood & 1.03 & 4.16 & 14.76 & 1.53 & 0.52 \\
\hline & Stembark & 0.49 & 1.32 & 5.07 & 1.57 & 0.57 \\
\hline & Petiole & 0.98 & 1.69 & 10.62 & 1.38 & 0.65 \\
\hline & Leaves & 2.87 & 7.18 & 9.76 & 0.58 & 0.43 \\
\hline \multirow[t]{4}{*}{$160 \mathrm{~g}$} & Stemwood & 0.49 & 3.39 & 8.88 & 0.81 & 0.46 \\
\hline & Stembark & 0.99 & 1.48 & 4.17 & 0.88 & 0.43 \\
\hline & Petiole & 0.32 & 1.50 & 7.43 & 0.61 & 0.42 \\
\hline & Leaves & 7.33 & 6.16 & 11.12 & 0.74 & 0.41 \\
\hline
\end{tabular}

Table 5. Amounts of nutrients accumulated by M. gigantea to produce one tonne of biomass twelve months after planting, together with the calculated N:P:K ratios, in response to different fertilizer treatments

\begin{tabular}{lcccccc}
\hline \multirow{2}{*}{ Fertilizer } & \multicolumn{3}{c}{$\begin{array}{c}\text { Nutrients accumulation } \\
\text { (kg ton }^{-\mathbf{1}} \text { ) }\end{array}$} & \multicolumn{3}{c}{ Ratio } \\
\cline { 2 - 6 } & $\mathbf{N}$ & $\mathbf{P}$ & $\mathbf{K}$ & $\mathbf{N}$ & $\mathbf{P}$ & $\mathbf{K}$ \\
\hline $0 \mathrm{~g}$ & 2.12 & 5.96 & 12.97 & 16.3 & 45.9 & 100 \\
$40 \mathrm{~g}$ & 2.70 & 6.52 & 17.02 & 15.9 & 38.3 & 100 \\
$80 \mathrm{~g}$ & 2.70 & 6.52 & 17.02 & 11.3 & 30.9 & 100 \\
$120 \mathrm{~g}$ & 2.38 & 6.36 & 17.83 & 13.3 & 35.6 & 100 \\
$160 \mathrm{~g}$ & 4.54 & 6.23 & 15.70 & 28.9 & 39.6 & 100 \\
\hline
\end{tabular}
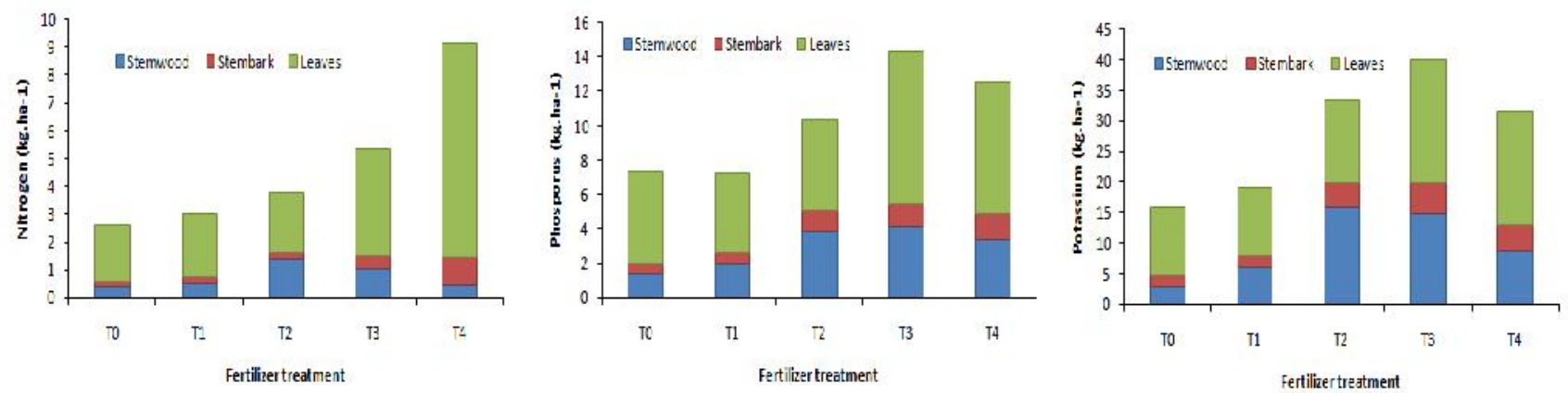

Figure 4. Amounts of N, P, and $\mathrm{K}$ accumulated in above-ground biomass $\left(\mathrm{kg} \mathrm{ha}^{-1}\right)$ of 1year old Macaranga gigantea 
Information about fertilizer treatment on the seedlings of some pioneer species, including $M$. gigantea in polybags was reported by Lawrence (2001) in West Kalimantan Indonesia. The study found that $\mathrm{N}$ had to be combined with $\mathrm{P}$ to optimize growth over the first 18 weeks. Application of $\mathrm{N}$ and $\mathrm{N}+\mathrm{P}$ fertilizers did not significantly increase the $\mathrm{N}$ content of the plant canopy, while application of $\mathrm{P}$ fertilizer alone significantly decreased $\mathrm{N}$ content of the canopy. Moreover, the application of $\mathrm{N}+\mathrm{P}$ fertilizer did not increase the $\mathrm{P}$ content of the plant canopy, while the application of $\mathrm{N}$ fertilizer alone decreased the $\mathrm{P}$ content of the plant canopy, and the application of $\mathrm{P}$ fertilizer alone did not significantly increase the $\mathrm{P}$ content of the plant canopy. The $\mathrm{N}$ concentration ranged between 15 to $20 \mathrm{mg} \mathrm{g}^{-1}$, while phosphorus concentration ranged between 1.7 and $2.7 \mathrm{mg}$ $\mathrm{g}^{-1}$ in the seedling canopy. On the other hand, Ishida et al. (2005) reported that the highest $\mathrm{N}$ concentration in $M$. gigantea leaves growing naturally was $2.5 \mathrm{~mol} \mathrm{~kg}^{-1}$ at the sapling stage and $2.0 \mathrm{~mol} \mathrm{~kg}^{-1}$ at the sucker stage, while the lowest nitrogen concentration was found at the seedling and mature stages, namely $1.5 \mathrm{~mol} \mathrm{~kg}^{-1}$. Breulmann et al. (2006) reported that phosphorus concentration in Macaranga in the natural forests in Malaysia ranged between $0.06 \%$ to $0.09 \%$, while potassium content was $0.71 \%$ to $0.82 \%$ in leaves only.

Susanto et al. (2014) reported that for $M$. gigantea, the highest $\mathrm{N}, \mathrm{P}$ and $\mathrm{K}$ concentrations occur in the leaves. In our study, the highest nitrogen concentration in the leaves of fertilized plants (in the $160 \mathrm{~g}$ fertilizer per plant treatment) was $0.813 \pm 0.53 \%$; the highest phosphorus concentration of $0.840 \pm 0.24 \%$ was in the wood of plants fertilized with $120 \mathrm{~g}$ of fertilizer per plant, while the highest potassium concentration of $3.513 \pm 0.73 \%$ was in the bark of plants fertilized with $120 \mathrm{~g}$ per plant.

There has been no information in the published literatre about the accumulation of $\mathrm{N}, \mathrm{P}$, and $\mathrm{K}$ nutrients in $M$. gigantea. In this study, the fertilization treatment of $120 \mathrm{~g}$ fertilizer per plant produced the highest above-ground biomass with the accumulation of $\mathrm{N}, \mathrm{P}, \mathrm{K}$ reaching 5.383 $\mathrm{kg} \mathrm{ha}^{-1}, 14.355 \mathrm{~kg} \mathrm{ha}^{-1}$ and $40.207 \mathrm{~kg} \mathrm{ha}^{-1}$ respectively. Nitrogen accumulation was $19.2 \%$ in wood, $9.2 \%$ in bark and $71.8 \%$ in leaves. The large accumulation of nitrogen in leaves was due to the high nitrogen concentration together with the high biomass production of leaves. This is in line with what was reported by Ishida et al. (2005). In that study, leaves of $M$. gigantea had the lowest nitrogen concentrate at seedling stage and the highest concentrate at the sapling stage. There is a gradual transition from seedling stage to sapling stage, with accumulation of plant $\mathrm{N}$ and development of the hydraulic system to face unexpected environmental stress.

In this study, the accumulation of phosphorus was $29 \%$ in wood, $9.2 \%$ in bark and $61.9 \%$ in leaves. The high accumulation of phosphorus in leaves was due mainly to the large amount of leaf biomass. The largest size for $M$. gigantea leaves is found at the sapling stage, reaching 60 $\mathrm{cm}$ long and $50 \mathrm{~cm}$ wide (Okuda 1996; Silk et al. 2000).
Accumulation of potassium in our study consisted of $36.7 \%$ in wood, $12.6 \%$ in barks and $50.7 \%$ in leaves.

The nutrient content of fast growing Eucaliptus deglupta in industrial plant forests in East Kalimantan (100 $\mathrm{m}^{3} \log$ and bark) was reported by Meckensen (1999) and Meckensen et al. (2001) as N: $44.4 \mathrm{~kg} \mathrm{ha}^{-1}$, P: $2.3 \mathrm{~kg} \mathrm{ha}^{-1}$ and $\mathrm{K}: 125 \mathrm{~kg} \mathrm{ha}^{-1}$. Rahmawati (1999) reported much less nutrient contents for the above-ground biomass of Eucaliptus deglupta at the age of 1 year; the contents were estimated to be $\mathrm{N}: 17.83 \mathrm{~kg} \mathrm{ha}^{-1}, \mathrm{P}: 1.68 \mathrm{~kg} \mathrm{ha}^{-1}$ and $\mathrm{K}$ : $41.16 \mathrm{~kg} \mathrm{ha}^{-1}$. Ruhiyat (1993) reported that forests of leda (Eucalyptus deglupta) and sengon (Paraseriantes falcataria) at the age of 5-10 years in East Kalimantan had accumulate potassium in largest amounts, followed by calcium, nitrogen and magnesium. Therefore, the conclusion has been that ensuring the availability of potassium is of high priority in the production of Eucalyptus stands.

Susanto et al. (2016b) and Susanto et al. (2017) reported that a positive correlation was observed between the $\mathrm{P}$ and $\mathrm{K}$ content of the leaves and the plant growth of $M$. gigantea in secondary forest after shifting cultivation and in forest gaps after selective logging.

In our study, the application of fertilizer at a dose of $120 \mathrm{~g}$ per plant produced the highest above-ground biomass and the highest accumulation of nutrients $\mathrm{P}$ and $\mathrm{K}$. In addition, the amount of nutrients accumulated in one tonne of biomass increased, with the highest amounts also being found in the $120 \mathrm{~g}$ fertilizer per plant, namely $2.38 \mathrm{~kg}$ of $\mathrm{N}$, $6.36 \mathrm{~kg}$ of $\mathrm{P}$, and $17.83 \mathrm{~kg}$ of $\mathrm{K}$ at an N:P:K ratio of 13.3: 35.6:100. There is no other published information that can be used as a comparison with this study as to the ratio of $\mathrm{N}: \mathrm{P}: \mathrm{K}$ required for $M$. gigantea to produce one tone of biomass. For another plant species, Uri et al. (2003) found that the amount of nutrients accumulated by a one year old grey alder in producing one tonne of biomass was $16.7 \mathrm{~kg}$ of $\mathrm{N}, 1.5 \mathrm{~kg}$ of $\mathrm{P}$ and $7.2 \mathrm{~kg}$ of $\mathrm{K}$ at an $\mathrm{N}: \mathrm{P}: \mathrm{K}$ ratio of 100:9:43.

In conclution, fertilizer treatment in our study increased growth, biomass production and nutrient accumulation in the components of $M$. gigantea plants. The best growth and production of above-ground biomass was found in plants to which $120 \mathrm{~g} \mathrm{NPK}$ fertiliser per plant was applied at the time of planting seedlings in the field, and again at the same dose level, six months later. The highest amounts of nutrient elements accumulated by $M$. gigantea at the age of one year were for potassium, followed by phosphorus, nitrogen, calcium and magnesium in declining order.

\section{ACKNOWLEDGEMENTS}

We acknowledge the Forest Education, Faculty of Forestry, Mulawarman University, Samarinda, Indonesia for providing permission to conduct the field work. The research was supported by decentralization research program of Mulawarman University, Indonesia. 


\section{REFERENCES}

Amirta R. 2010. Potential utilization of tropical lignocellulosic biomas for biofuels-bioenergy production in East Kalimantan. JSPS Exchange Program for East Asian Young Researchers: "Fostering Program of Leading Young Scientists toward the Establishment of Humanosphere Science in East Asia", Shigaraki, Kyoto, Japan.

Amirta R, Nafitri SI, Wulandari R, Yuliansyah, Suwinarti W, Candra KP, Watanabe T. 2016a. Comparative characterization of Macaranga species collected from secondary forest in East Kalimantan for biorefinery of unutilized fast growing wood. Biodiversitas 17 (1): 116-123

Amirta R, Mukhdlor A, Mujiasih D, Septia E, Supriadi, Susanto D. 2016b Suitability and availability analysis of tropical forest wood species for ethanol production: a case study in East Kalimantan. Biodiversitas 17 (2): $544-552$

Anonymous. 2012. Meteorology, climatology and geophysics station of Temindung Airport Samarinda, East Kalimantan. Indonesia

Breulmann G, Markert B, Weckret V, Herpin U, Yoneda R, Ogino K. 2002. Heavy metals in emergent trees and pioneers from tropica forest with special reference to forest fires and local pollution sources in Sarawak, Malaysia. Sci Total Environ 285: 107-115.

Chen JW, Zhang Q, Li XS, Cao KF. 2009. Independence of stem and leaf hydraulic traits in six Euphorbiaceae tree species with contrasting leaf phenology. Planta 230: 459-468.

Davies SJ. 1998. Photosynthesis of nine pioneer Macaranga species from Borneo in relation to life history. Ecology 79: 2292-2308

Eichhorn KAO. 2006. Plants diversity after rain-forest fires in Borneo. Blumea Supplement 18 Nationaal Herbarium Netherland, Universitei Leiden branch.

Hiratsuka M, Toma T, Diana R, Hadriyanto D, Morikawa Y. 2006. Biomass recovery of naturally regenerated vegetation after the 1998 forest fire in East Kalimantan, Indonesia. Japan Agric Res Quart 40 (3): $277-282$

Ishida A, Yazaki K, Hui AL. 2004. Ontogenetic transition of leaf physiology and anatomy from seedlings to mature trees of a rain forest pioneer tree, Macaranga gigantea. Oxford J 25 (5): 513-522.

Lawrence D. 2001. Nitrogen and phosporus enhances growth and luxury consumption of four secondary forest tree species in Borneo. J Trop Ecol 17: 859-869.

Lawrence D. 2005. Biomass accumulation after 10-200 years of shifting cultivation in Bornean rain forest. Ecology 86: 26-33

Manokaran N, Kochummen KM. 1992. Tree growth in primary lowland and hill dipterocarp forests. J Trop For Sci 6 (3): 332-345.

Meckensen J, Ruhiyat D, Folster H. 2001. Volume-based nutrient content of Acacia mangium, Eucalyptus deglupta and Paraserianthes falcataria in industrial tree plantations in East Kalimantan, Indonesia. J Trop For Sci 13: 512-526.

Meckensen J. 1999. Nutrient Management for Industrial Tree Plantation. A Practical Guidance towards Integrated Nutrient Management. Deutsche Gesellschaft fur Technische Zusammenarbeit (GTZ) GmbH Postfach 5180. D-65726, Eschborn.
Nussbaum R, Anderson J, Spenser T. 1995. Factors limiting growth of indigenous tree seedlings planted on degradated rain forest soil in Sabah, Malaysia. For Ecol Manag 74: 149-159

Okuda T. 1996. Studies on Potential Growth and Photosynthesis Capacity of Trophical Tree Seedlings. National Institute for Environmental Studies, Environment Agency, Japan.

Rahmawati. 1999. Distribution of the Soil Nutrient and Stands of Eucalyptus deglupta Blume, Age 1, 2, 3.4 and 6 years in the Industrial Forest Plantation PT ITCI in Pasir Regency. [Thesis]. Faculty of Forestry, University Mulawarman. Samarinda, Indonesia. [Indonesian]

Romell EG, Hallsby G, Karlsson A, Garcia C. 2008. Artificial canopy gaps in a Macaranga spp. dominated secondary tropical rain forest effects on survival and above ground increment of four under-planted dipterocarp species. For Ecol Manag 255: 1452-1460.

Ruhiyat D. 1993. Nutrient dynamics in Forest Utilization of Natural and Plantation Forest: Forest Biogeochemistry Cycles. In: Sutisna M, Ruhiyat D, Ruchaimi A. (eds.). Proceedings of the Workshop of Forest Management Environmental humid tropics to Increase Productivity (pp 13-26. Ministry of Forestry Republic of Indonesia and, Mulawarman University, Samarinda, Indonesia. [Indonesian]

Ruhiyat D. 1996. Estimasi biomassa tegakan hutan hujan tropis di Kalimantan Timur. Rimba Kalimantan 1 (1): 42-57.

Slik FJW, Bernard CS, Van Beek M, Breman FC, Eichhorn KAO. 2008. Tree diversity, composition, forest structure and aboveground biomass dynamics after single and repeated fire in a Bornean rain forest. Oecologia. Springer-Verlag DOI 10.1007/s0042-008-1163-2.

Slik FJW, Priyono, Van Welzen PC. 2000. Key to the Macaranga Thou. and Mallotus Lour. species (Euphorbiaceae) of East Kalimantan, Indonesia. Gardens' Bulletin Singapore 52: 11-87.

Susanto D, Hayatudin, Setiawan A, Purnomo H, Ruhiyat D, Amirta R. 2017. Characterizing nutrient status and growth of Macaranga gigantea in tropical rainforest gaps after selective logging in East Kalimantan, Indonesia. Biodiversitas 18 (3): 996-1003.

Susanto D, Ruhiyat D, Sutisna M, Amirta R. 2014. Early nutrient needs of plants Mahang (Macaranga gigantea). Proceedings of the National Seminar Silvicultur II. Gadjah Mada University, Yogyakarta 28-29 Agustus 2014, Indonesia. [Indonesian]

Susanto D, Ruhiyat D, Sutisna M, Amirta R. 2016a. Flowering, fruiting, seed germination and seedling growth of Macaranga gigantea. Biodiversitas 17 (1): 192-199.

Susanto D, Ruhiyat D, Sutisna M, Amirta R. 2016b. Soil and leaf nutrient status on growth of Macaranga gigantea in secondary forest after shifting cultivation in East Kalimantan, Indonesia. Biodiversitas 17 (2): 409-416

Suzuki E. 1999. Diversity in specific gravity and water content of wood among Bornean tropical rainforest trees. Ecol Res 14 (3): 211-224.

Uri V, Tullus H, Lohmus K. 2003. Nutrient allocation, accumulation and above-ground biomass in Grey Alder and Hybrid Alder plantations. Silva Fennica 37 (3): 301-311

Yamada T, Okuda T, Abdullah M, Awang M, Furukawa A. 2000. The leaf development process and its significance for reducing self-shading of a tropical pioneer tree species. Oecologaia 125 (4): 476-482. 